\title{
Codificando mensagens: uma metodologia de ensino de matrizes por meio da Criptografia
}

\author{
Cristiano Marinho da Silva, Maria Aparecida da Silva, Mirtes de Souza Silva \\ Universidade Federal de Alagoas, UFAL, Campus Arapiraca \\ 15054-000, Arapiraca,AL \\ E-mail: cristiano.cms.mat@gmail.com,mariahcastrosilva@gmail.com,mirtes_souza_silva@hotmail.com
}

\begin{abstract}
RESUMO
O presente trabalho trás o relato de uma intervenção que buscou a fixação de conceitos relacionados a Matrizes e algumas de suas operações por meio da Criptografia. A atividade foi realizada por alunos do curso de Matemática Licenciatura da Universidade Federal de AlagoasUFAL, Campus Arapiraca, bolsistas do Programa de Iniciação à Docência - PIBID na Escola Professor José Quintella Cavalcanti, em parceria com a professora supervisora Rosenilda dos Santos em duas turmas do $2^{\circ}$ Ano do Ensino Médio.

Fundamentando a proposta de intervenção atentou-se para o fato de que a Criptografia comumente utilizada nos meios de informações, em destaque no mundo virtual, pode ser uma alternativa educacional para que se transforme o modo de ver a matemática, desvencilhando a ideia de que ela está ao alcance apenas dos "desprovidos de razão" ou mesmo de alguns iluminados detentores do conhecimento matemático. É por meio de ações diferenciadas do educador matemático que tal concepção pode ser substituída, despertando em seus alunos o gosto pela busca de conhecimentos, assim como, permite que tal profissional não só se utilize dos métodos tradicionais e propicie assim, a conexão da matemática com diversas áreas do conhecimento, o que facilita a ampliação dos olhares dando significado aos conceitos.
\end{abstract}

O caráter abstrato da matemática exige do docente a capacidade de desenvolver metodologias de ensino, buscando a facilitação da aprendizagem. Dentre estes métodos destacamos o uso de jogos envolvendo situações-problema, que ao serem tratados com menos formalidade, estimula o aprendizado do conteúdo tratado.

"Outro motivo para a introdução de jogos nas aulas de matemática é a possibilidade de diminuir bloqueios apresentados por muitos de nossos alunos que temem a Matemática e sentem-se incapacitados para aprendê-la. Dentro da situação de jogo onde é impossível uma atitude passiva e a motivação é grande, notamos que ao mesmo tempo em que estes alunos falam Matemática, apresentam também um melhor desempenho e atitudes mais positivas frente a seus processos de aprendizagem." (BORIN, 1996. p. 9)

Legitimada a concepção de que se torna necessário a utilização de metodologias de ensino diferenciadas e que possibilite aos alunos sentirem-se cativados pela matemática, desenvolveu-se uma atividade pautada em três momentos:

1) o primeiro momento constou da apresentação e debate a respeito da Criptografia, seu histórico, seus principais teóricos, sua diversidade de aplicações no mundo atual e, não obstante, como ela pode ser usada no estudo de matrizes. Esse foi um momento importante para medir o grau de conhecimento a respeito do assunto por parte dos alunos, proporcionando a troca de informações e experiências entre os próprios alunos, e entre eles e os bolsistas;

2) o segundo momento constou da explicação da dinâmica, quais os conceitos matemáticos que 
seriam utilizados para a sua realização e como seriam usados esses conceitos;

3) por fim, o terceiro momento foi a realização da dinâmica que foi organizada da seguinte forma:

3.1) Divisão da turma: A turma foi dividida em 6 grupos (independente do número de alunos que a turma contenha) os quais foram nomeados (A, B, C, D, E, F, por exemplo);

3.2) Desenvolvimento: Foi proposto a cada grupo codificar uma mensagem (tempo máximo de $8 \mathrm{~min}$.) e as mensagens codificadas foram trocadas entre os grupos, dois a dois, para serem decodificadas ao mesmo tempo. Isso corresponde a uma rodada. A cada rodada duas equipes foram desclassificadas. O jogo foi composto de 3 (três) rodadas. A (rodada) final ocorreu entre as duas equipes que passaram as duas primeiras rodadas. $\mathrm{O}$ grupo vencedor teve uma gratificação.

A criptografia, ao longo do tempo, vem sendo usada como técnica de segurança, num mundo onde há a necessidade de ocultar informações ou protegê-las de possíveis invasões em informações sigilosas, sendo um recurso muito utilizado na área da informática, já que nomeio virtual existem hackers que estão sempre dispostos a modificar os softwares e invadir a privacidade alheia. Além disso, em iniciativas como Projeto Institucional de Iniciação à Docência- PIBID ela está sendo utilizada como um método de dinamização de aulas e conteúdos matemáticos concernentes principalmente aos assuntos de matrizes e funções, despertando nos alunos o interesse por essa ciência, tendo em vista o melhoramento do processo ensino-aprendizagem da matemática. Uma experiência como essa serve, além da dinamização da aula, como um meio de avaliação da real possibilidade de obter resultados positivos no que diz respeito à fixação de conteúdos, e não só isso, mas principalmente a instigação dos alunos para ver de uma forma mais divertida e atrativa a disciplina tão temida e rejeitada: MATEMÁTICA.

Palavras-chave: criptografia, codificação, educação matemática, matrizes.

\section{Referências}

[1] Borin, J. Jogos e Resoluções de Problemas: uma estratégia para as aulas de matemática. São Paulo: IME - USP; 1996.

[2] Matrizes e Criptografia. Publicado em: http://educacaomatematica2010.blogspot.com/2011/01/matrizes-e-criptografia.html. Consultado em: 20/07/2012. 